\title{
Nematode communities act as bio-indicator of status and processes of an agricultural soil ecosystem in Thanh An, Binh Phuoc province
}

\author{
Quần xã tuyến trùng giũ vai trò nhu chỉ thị sinh học của trạng thái và các quá \\ trình của hệ sinh thái đất nông nghiệp ở Thanh An, tỉnh Bình Phước
}

Research article

Duong, Duc Hieu ${ }^{1 *}$; Le, Thi Phuong Anh ${ }^{2}$; Bui, Thi Thu Nga ${ }^{1}$;go, Xuan Quang ${ }^{1}$; Nuyen, Dinh Tu ${ }^{3}$; Nguyen, Huu Hung ${ }^{1,4}$; Nguyen, Vu Thanh ${ }^{3}$

${ }^{1}$ Institute of Tropical Biology, Vietnam Academy of Science and Technology (VAST). 9/621 Hanoi highway, Linh Trung ward, Thu Duc district, HCM city, Vietnam; ${ }^{2}$ University of Science, Vietnam National University of Ho Chi Minh City; ${ }^{3}$ Institute of Ecology and Biology Resources, VAST. 18 Hoang Quoc Viet, Cau Giay, Hanoi, Vietnam; ${ }^{4}$ Nguyen Tat Thanh University, 300A Nguyen Tat Thanh, Dist.4, Ho Chi Minh City

\begin{abstract}
Nematode communities in black pepper (Piper nigrum L.) agricultural soil in Thanh An, Binh Phuoc province, were investigated. Soil samples were collected in February 2012 at 9 selected sites belonging to 3 pepper groves. The structure of nematode communities and critical ecological indices were determined to estimate environmental status. 26 genera were found. Of those, plant parasitic nematodes such as Meloidogyne, Helicotylenchus, Hoplolaimus, Psilenchus, and Tylenchidae always appear with high frequency and density, whereas the carnivorous nematodes were rarely detected. The nematode density correlates to the concentration of the total organic matter which correlates closely to the $(\mathrm{Ba}+\mathrm{Fu})$ proportion showed by the regression equation $\mathrm{y}=$ $0.0223 x+1.6819$ with $\mathrm{R}^{2}=1$. The ecological triangle model, but not the maturity index (MI), apparently showed the status and processes (decomposition and mineralization) which may be happening in the soils of areas studied. The first grove is rich in nutrient but stressed by chemicals. The second grove is stable, with no chemical stress, but has low nutrient contents. The third grove is affected by chemicals but to a lesser extent than the first one.
\end{abstract}

Các quần xã tuyến trùng trong hệ sinh thái đất trồng tiêu ở khu vực xã Thanh An, tỉnh Bình Phước được nghiên cưu. Các mẫu đất được thu nhận trong tháng hai năm 2012 tại 9 điểm thuộc 3 vuờn tiêu. Cấu trúc quần xã tuyến trùng và các chỉ số sinh thái đã được xác định để qua đó đánh giá trạng thái môi truờng. Tổng cộng có 26 giống tuyến trùng được tìm thấy. Trong đó, các loài tuyến trùng ký sinh thục vật nhu Meloidogyne, Helicotylenchus, Hoplolaimus, Psilenchus, và tuyến trùng ăn nấm Tylenchidae luôn xuất hiện với tần suất và mật độ cao, trong khi tuyến trùng ăn thịt lại hiếm khi được phát hiện. Mật độ tuyến trùng tuơng quan với lương chất hũu co tổng số mà nó tuong quan chặt chẽ vớ với tỉ lệ nhóm $(B a+F u)$ được thể hiện ở phuoong trình hồi quy là y = $0.0223 x+1.6819$ với $R^{2}=1$. Mô hình tam giác sinh thái, nhưng không phải chỉ số tăng trưởng MI, thể hiện rõ trạng thái và các quá trình (sụ phân hủy và sự khoáng hóa) có lẽ đang diễn ra trong đất của khu vục được nghiên cứu. Vườn thư nhất thì giàu dinh duõng nhưng bị áp lực bởi hóa chất. Vườn thứ hai khá ổn định, không chịu áp lục hóa chất, nhung hàm lượng dinh duõng rất kém. Vườn thứ ba bị tác động bởi hóa chất nhưng ở mức độ thấp hơn vuờn thứ nhất.

Keywords: nematode community, ecological triangle model, trophic group, ecological index, Thanh An, Piper nigrum 


\section{Introduction}

Managed agro-ecosystems typically have low levels of biodiversity, internal interactions, and feedback mechanisms. The system inputs and outputs are determined by human activites. The internal biotic regulation of the system is therefore decreased or eliminated (Diana W. Freckman and Edward P. Caswell, 1985). The relationships between organisms usually are disturbed. Because of economic competition, agricultural soils become more and more polluted when chemical fertilizers, pesticides, etc have been widely used. The ability to monitor and assess the quality of agroecosystem soils becomes importance, particularly to farming managers who could modify their farming strategies (D.L. Porazinskaa, L.W. Duncanb, 1999).

Soil nematodes were considered as a reliable bioindicators of the status and processes of an ecosystem (D.L. Porazinskaa, L.W. Duncanb, 1999). Nematodes possess the most important characteristics of any prospective bioindicator: abundance in virtually all environments, diversity of life strategies and feeding habits (Freckman, 1988; Yeates et al., 1993a), short life cycles, and relatively welldefined sampling procedures. Nematodes vary in sensitivity to pollutants and environmental disturbance. Recent development of indices that integrate the responses of different taxa and trophic groups to perturbation provides a powerful basis for analysis of faunal assemblages in soil as in situ environmental assessment systems (Tom Bongers and Howard Ferris, 1999). For these reasons, several researchers have attempted to study relationships between nematode community structure and succession of natural ecosystems or environmental disturbance (Ettema and Bongers, 1993; Deborah A. Neher et.al, 1999; Christian Mulder et.al, 2005, Howard Ferris and Tom Bongers, 2006). In recent years, the idea that using soil nematodes for assessment and monitoring the quality of agroecological soils has been investigated (Ferris et al., 1996; Yeates et al., 1997, Nguyen Ngoc Chau and Vu Thanh Tam, 2005, Duong Duc Hieu et al., 2009). The measurement of nematode community patterns illustrates the soil condition and plays as a useful tool for soil environmental managing.

In this study, the nematode communities in black pepper (Piper nigrum L.) agricultural soil were investigated. The objectives of this study were to: (1) characterize nematode communities (taxonomic and ecological index description) in soils from 3 pepper groves exposed to different agricultural management practices; (2) evaluate whether soil ecosystem differences imposed by farming tactics can be reflected by nematode characterization.

\section{Material and methods}

\subsection{Soil sampling}

Soil samples were collected from 3 pepper groves in Thanh An, Binh Phuoc province - one of pepper-growing areas in Vietnam. Thanh An is the pepper cultivation area of Binh Phuoc. In the first grove, soil contained wet and fine particles and was annually treated with chemical fertilizers such as NPK, animal manures with rice husk, and Mocap nematicide. The second grove was abandoned because of destroying by parasitic nematodes. Soil in this area was dry and coarse sand. The third grove was treated with chemical fertilizers, water, and microbial fertilizer.

\subsection{Nematode isolation, determination, and classification}

Soil samples were collected from each plot at $10-15 \mathrm{~cm}$ depth on February 2012. These sites - rhizosphere soil of pepper tree - were collected at each grove, and three replicate cores were taken at each site. Each sample, comprised about $400 \mathrm{~g}$ soil, was placed in an individual plastic bag and then immediately brought to laboratory. Nematodes were extracted from $100 \mathrm{~g}$ soil of each sample by decanting and gradient centrifugation with sugar media (Nic Smol, 2007). Total amount of nematodes were counted on the square counting dish. Nematodes were then picked up and mounted (Nic Smol, 2007) for morphological analysis. 200 individuals per site were randomly selected and identified to taxonomic genus according to Fauna in Vietnam (Nguyen Ngoc Chau and Nguyen Vu Thanh, 2000; Nguyen Vu Thanh, 2007). Nematodes were classified into five trophic groups including bacterivores, fungivores, omnivores, predators, and plant parasites (Yeates et al., 1993). The determination of nematode types is along the colonization-persistence gradient (Bongers, 1988 and 1990).

\subsection{Ecological indices}

The maturity index MI and PPI was determined as showed previously (Bongers, 1990);

MI $=\sum_{i=1}^{n} v(i) x f(i)$, where $v(i)$ is the c-p value of taxon $i$ of free-living groups, $f(i)$ is the frequency of taxon $i$ of free-living groups in a sample.

PPI $=\sum_{i=1}^{n} v(i) \times f(i)$ where $v(i)$ is the c-p value of taxon $i$ of plant-parasitic groups, $f(i)$ is the frequency of taxon $i$ of plant-parasitic groups in a sample.

An ecological triangle (graphical representations of faunal composition) was constructed. In equilateral $\mathrm{cp}$ triangles, two enrichment (\% c-p1 and \% c-p2) axes and an ecosystem complexity (\% cp-3-5) axis were accommodated by unweighted proportions of the nematode fauna in each grouping (De Goede et al., 1993; Ettema and Bongers, 1993).

\subsection{Total organic matter (TOM) analysis}

Soil samples from each grove were mixed and TOM was determined according to the Walkeyblac method (Le Van Khoa et al, 2000)

\section{Results and discussion}

The result of nematode density showed in Figure 1. There is a variation between sampling sites. The nematode population density is from 80 to 11124 individuals $/ 100 \mathrm{~g}$ soil. Grove 1 and grove 2 are the groves 
have highest density and lowest density, respectively $(\alpha=0.05)$.

About 25 genera belonged to 17 families were identified in all of samples. Of those, there are 17 genera in the first grove, 10 genera in the second grove, and 11 genera in the last grove. The common taxa were Filenchus, Psilenchus (Tylenchidae), Aphenlenchoides (Aphelenchoidae), Meloidogyne (Heteroderidae), Helicotylenchus and Hoplolaimus (Hoplolaimidae). Fungivores Tylenchidae (cp-2) is abundance in the first grove. In contrast, plant parasites such as Meloidogyne (cp-3) and Hoplolaimidae (cp-3) are predominated in the others. Results of identifying and calculating ecological index were listed in Table 1 .

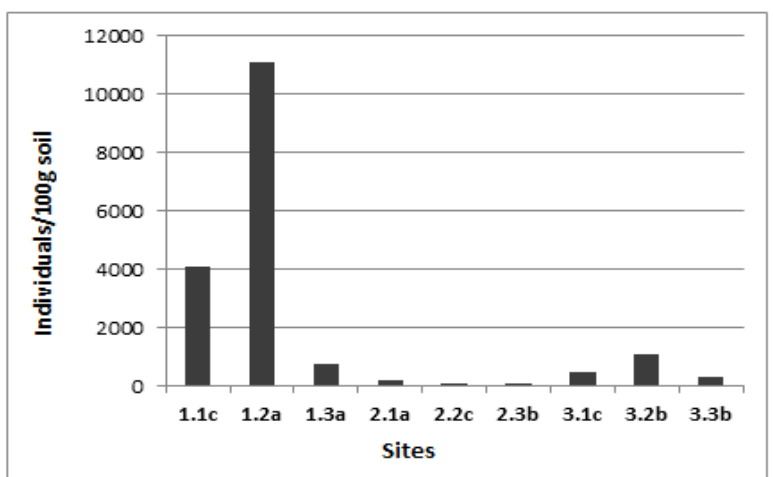

Figure 1. The nematode population density

Table 1. Ecological indices of pepper soil in Thanh An, Binh Phuoc province

\begin{tabular}{|c|c|c|c|c|c|c|c|c|c|c|}
\hline \multirow[b]{2}{*}{ No. } & \multirow[b]{2}{*}{ Trophic groups } & \multicolumn{9}{|c|}{ Sampling sites } \\
\hline & & $1.1 \mathrm{c}$ & $1.2 \mathrm{a}$ & $1.3 \mathrm{a}$ & $2.1 \mathrm{a}$ & $2.2 \mathrm{c}$ & $2.3 \mathrm{~b}$ & $3.1 \mathrm{c}$ & $3.2 \mathrm{~b}$ & $3.3 b$ \\
\hline & Bacterivores (Ba) & & & & & & & & & \\
\hline 1 & Prismatolaimus sp. & & & & & $\mathrm{x}$ & & & & \\
\hline 2 & Paraplectonema sp. & & & & & & & $\mathrm{x}$ & & \\
\hline 3 & Paramphidelus sp. & & & & & & & & $\mathrm{x}$ & \\
\hline 4 & Eucephalobus sp. & & & $\mathrm{x}$ & & & & $\mathrm{x}$ & & $\mathrm{x}$ \\
\hline 5 & Cephalobus sp. & & & & & & & $\mathrm{x}$ & & \\
\hline 6 & Panagrolaimus sp. & & & & & & & & $\mathrm{x}$ & $\mathrm{x}$ \\
\hline 7 & Heterocephalobus sp. & & & & & & & $\mathrm{x}$ & & \\
\hline \multirow[t]{2}{*}{8} & Megadorus sp. & & & & & & & & & $\mathrm{x}$ \\
\hline & Fungivores (Fu) & & & & & & & & & \\
\hline 9 & Aphelenchoides sp. & $\mathrm{x}$ & $\mathrm{x}$ & & & $\mathrm{x}$ & $\mathrm{x}$ & & $\mathrm{x}$ & \\
\hline 10 & Filenchus sp. & $\mathrm{x}$ & $\mathrm{x}$ & $\mathrm{x}$ & & $\mathrm{x}$ & $\mathrm{x}$ & $\mathrm{x}$ & $\mathrm{x}$ & $\mathrm{x}$ \\
\hline 11 & Ecphyadophoroides sp. & & & $\mathrm{x}$ & & & & & & \\
\hline 12 & Aglenchus sp. & & & $\mathrm{x}$ & & & & & & \\
\hline \multirow{2}{*}{13} & Aphelenchus sp. & & & & $\mathrm{x}$ & $\mathrm{x}$ & $\mathrm{x}$ & & & $\mathrm{x}$ \\
\hline & Predators (Pre) & & & & & & & & & \\
\hline 14 & Molonchulus sp. & & & & $\mathrm{x}$ & & & & & \\
\hline \multirow[t]{2}{*}{15} & Aprutides sp. & & & & & & & & $\mathrm{x}$ & \\
\hline & Omnivores (Om) & & & & & & & & & \\
\hline 16 & Aporcelaimellus sp. & & & $\mathrm{x}$ & & & & & & \\
\hline \multirow[t]{2}{*}{17} & Aporcelaimellus sp. & & & & & & & & $\mathrm{x}$ & \\
\hline & Plant Parasites (Pp) & & & & & & & & & \\
\hline 18 & Psilenchus sp. & $\mathrm{x}$ & & $\mathrm{x}$ & $\mathrm{x}$ & & & $\mathrm{x}$ & $\mathrm{x}$ & $\mathrm{x}$ \\
\hline 19 & Meloidogyne sp. & $\mathrm{x}$ & $\mathrm{x}$ & $\mathrm{x}$ & $\mathrm{x}$ & $\mathrm{x}$ & $\mathrm{x}$ & & $\mathrm{x}$ & \\
\hline 20 & Longidorus sp. & $\mathrm{x}$ & & $\mathrm{x}$ & & & $\mathrm{x}$ & & & \\
\hline 21 & Tylenchulus sp. & & $\mathrm{x}$ & $\mathrm{x}$ & & & & & $\mathrm{x}$ & \\
\hline 22 & Helicotylenchus sp. & & & & $\mathrm{x}$ & $\mathrm{x}$ & & $\mathrm{x}$ & $\mathrm{x}$ & $\mathrm{x}$ \\
\hline 23 & Hoplolaimus sp. & & & & & $\mathrm{x}$ & & & & $\mathrm{x}$ \\
\hline 24 & Pratylenchus sp. & & & & & & & $\mathrm{x}$ & $\mathrm{x}$ & \\
\hline \multirow[t]{9}{*}{25} & Rotylenchulus sp. & & & & & & & & $\mathrm{x}$ & \\
\hline & Ecological indices & & & & & & & & & \\
\hline & $\overline{\mathrm{MI}}$ & 1 & 1.75 & 1.07 & 0.10 & 0.41 & 0.19 & 1.6 & 0.57 & 0.57 \\
\hline & PPI & 1.11 & 0.29 & 1.41 & 2.87 & 2.44 & 2.75 & 0.54 & 1.80 & 2.01 \\
\hline & $\mathrm{PPI} / \mathrm{MI}$ & 1.11 & 0.17 & 1.32 & 28.7 & 5.95 & 14.5 & 0.34 & 3.16 & 3.53 \\
\hline & TMI2-5 & 2.11 & 2.03 & 2.47 & 2.97 & 2.85 & 2.94 & 2.14 & 2.31 & 2.57 \\
\hline & \%c-p 1 & 0.00 & 0.00 & 0.00 & 0.00 & 0.00 & 0.00 & 0.00 & 0.06 & 0.01 \\
\hline & $\% c-p 2$ & 0.93 & 0.97 & 0.62 & 0.05 & 0.15 & 0.08 & 0.86 & 0.49 & 0.39 \\
\hline & $\%$ c-p 3-5 & 0.07 & 0.03 & 0.38 & 0.95 & 0.85 & 0.92 & 0.14 & 0.45 & 0.59 \\
\hline
\end{tabular}

The main trophic group is plant parasites. The Figure 2 shows trophic groups of samples from 3 groves. (Pre + $\mathrm{Om})$ nematodes rarely detected in all groves. Samples of the second groves have high proportion of plant parasites and low proportion of the total bacterivores and fungivores $(\mathrm{Ba}+\mathrm{Fu})$. These also happen to the third grove but to a lesser extent. In contrast, $(\mathrm{Ba}+\mathrm{Fu})$ is predominant in samples collected from the first grove.

We next ask whether the nematode communities relate to the content of TOM in soils. The TOM was determined. We found that TOM is different among the groves: 
$3.49 \%, 1.87 \%$, and $2.75 \%$ in the first, the second, and the third grove, respectively. In addition, we found that the TOM correlates closely to the proportions of $(\mathrm{Ba}+\mathrm{Fu})$. The regression equation between them is $\mathrm{y}=0.0223 \mathrm{x}$ +1.6819 with $\mathrm{R}^{2}=1$ (Figure 3 ). The high level of TOM stimulates decomposing process by fungi and bacteria, provides more nutrients for root, and increases the protective abilities of plant. Moreover, the high abundance of fungi and bacteria helps to reduce plant parasitic nematodes, which are the host of these microorganisms (Robert Mcsorley, 2011).

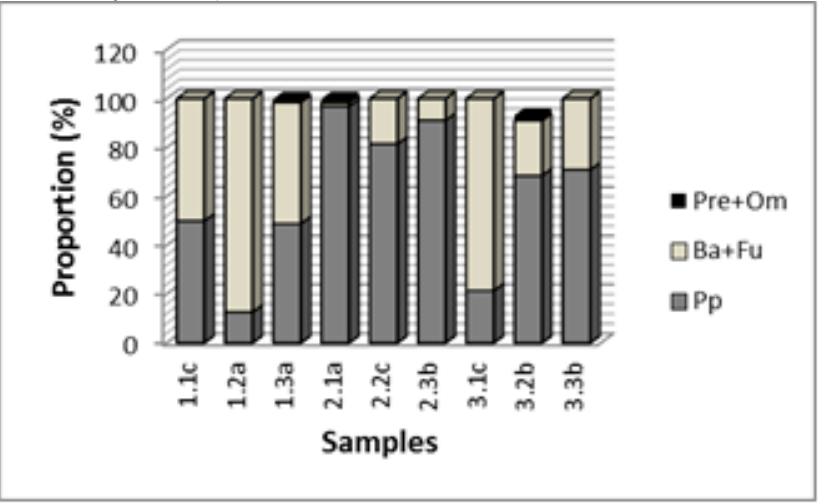

Figure 2. The proportion of trophic groups in samples

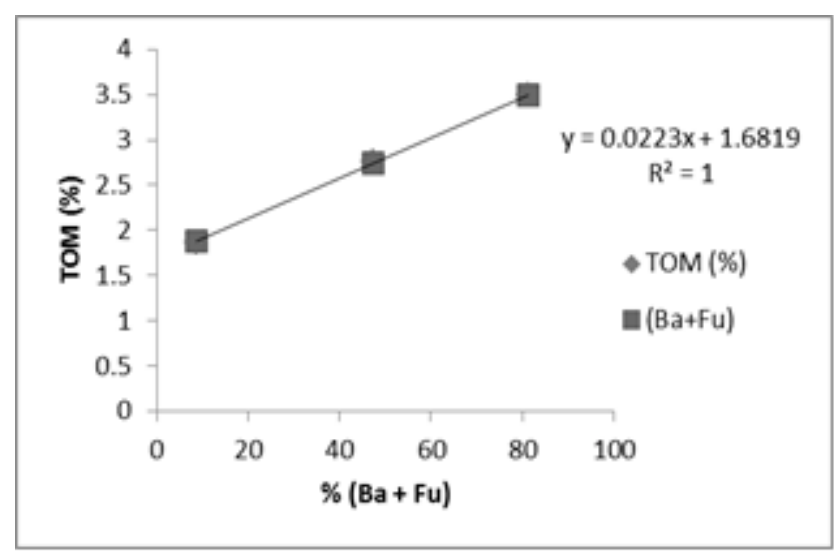

Figure 3. Relationship between the TOM and the proportion of $(\mathrm{Ba}+\mathbf{F u})$

Total numbers of nematodes range from 80 to 174 and from 488 to 1075 per $100 \mathrm{~g}$ soil of samples collected from the second grove and the third grove, respectively. However, nematode numbers in the first grove samples are significantly $(\mathrm{p}<0.01)$ higher than the others. This pattern is driven mostly by bacterivorous and fungivorous nematodes.

The ecological triangle model clearlier reflects the soil status than does the Maturity index (TMI2-5). The comparison of result of TMI2-5 shows: grove $2>$ grove $3>$ grove 1 . The ecological triangle model shows: points of the first grove stay on the right angle reflecting stressed status by chemicals and high nutrient. The second grove is quite stable and pure but has low nutrient because points stay on the left angle. The third is seriously affected but less stress than the first. The results completely appropriate to the reality information: the first grove was annually treated with chemical fertilizers, the animal manures with rice husk, and nematicide Mocap. The second grove was abandoned because of destroying by parasitic nematodes. Soil in this area was dry and coarse sand. The third grove was treated with chemical fertilizers, water, and microbial fertilizer.

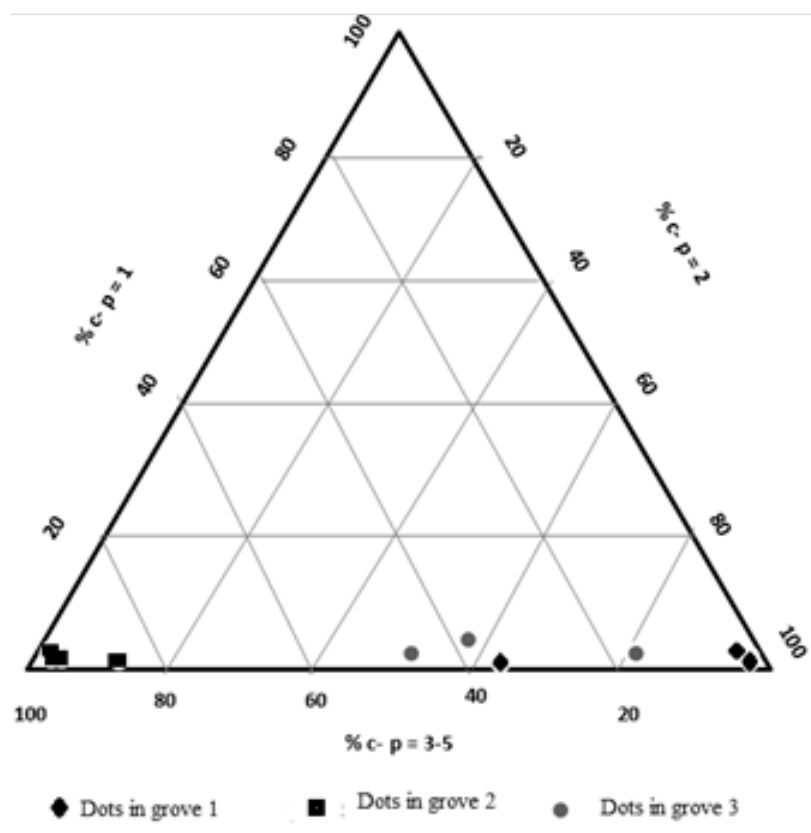

Figure 4. The ecological triangle model

The sex ratio of nematode communities is shown in Figure 5. Nematode communities of the second and the third grove had large numbers of the second-stage juveniles (J2) of Meloidogyne. However, there was an equivalence between male and female in Helicotylenchus in the third grove. In the first grove, Filenchus sp. has higher rates than other genera. For Diana W. Freckman and Edward P. Caswell (1985), the gender ratio of nematodes can different within species and they can be affected by the environment. The disparity in the sex ratio species may be due to mortality of male and female different. The parasitic plant species are more likely to move lower, so the population is often associated with the natural conditions of the area. However, the cause of the evolution of the sex ratio is complex and poorly understood much. 


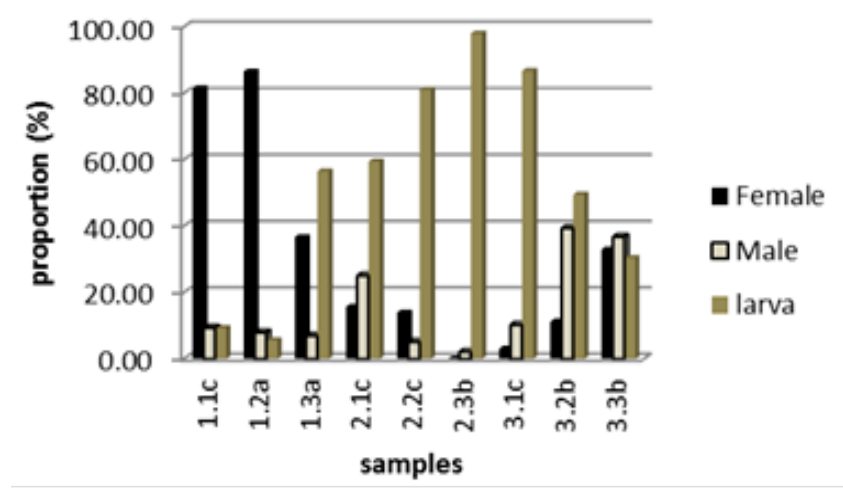

Figure 5. Sex ratios at samples

\section{Conclusion}

Nematode communities of pepper-growing soil ecosystems in Thanh An, Binh Phuoc provine was characterized by high numbers of plant parasitic nematodes in which the most common is Meloidogyne, Helicotylenchus, Hoplolaimus, and Psilenchus. The common genera of fungivorous nematodes were Filenchus, Aphelenchoides, and Aphelenchus avenae. Their abundance possibly depends on content of TOM in soil.

The structure of nematode communities can reflects the status and processing in soil. The ecological triangle model was positive tool for assessing and monitoring. Our data suggest that soil nematodes should be considered as important bio-indicator which can be applied to monitor changes in soil agriculture environment and provide methods of soil treatment prior to culture. However, molecular biological approaches are required in further investigations to accurately determine the appearance of nematodes which are undetectable by mophological analysis in this study.

\section{Acknowledgement}

This study was funded by No. VAST04.09/13-14 the Vietnam Academy of Science and Technology. We thank Prof. Nguyen Vu Thanh, Institute of Ecology and Biology Resources, VAST, for discussion and critical reading of the manuscript.

\section{References}

[1] Bongers T. and Ferris H., 1999. Nematode community structure as a bioindicator in environmental monitoring. TREE, Vol.14, No. 6: 224-228.

[2] Bongers T. and Ferris H., 2006. Nematode Indicators of Organic enrichment. Journal of Nematology, 38: 3-12.

[3] Christian Muldera, et al., 2005. The use of nematodes in ecological soil classification and assessment concepts. Ecotoxicology and Environmental Safety 62: 278-289.

[4] Deborah A. et al., 1999. Grazing in a porous environment. 2. Nematode community structure. Plant and Soil, 212: 85-99.

[5] Diana W. Freckman and Edward P. Caswell, 1985. The ecology of nematodes in Agroecosystems. Ann. Rev. Phytopathol, 23: 275-296.

[6] Duong Duc Hieu, Ngo Xuan Quang, Nguyen Vu Thanh, Pham Minh Duc, 2009. Using nematode communities as bio-indicator to assess the soil quality in An Thanh, Thuan An, Binh Duong province. Proceedings of the 3st National Workshop on Ecology and Biological Resources, Hanoi, p.13341340 .

[7] Elliot, E.T., Cole, C.V., 1989. A perspective on agroecosystem science. Ecology, 70: 1597-1602.

[8] Ettema, C.H., Bongers, T., 1993. Characterization of nematode colonization and succession in disturbed soils using the Maturity Index. Biol. Fertil. Soils, 16: 79-85.

[9] Freckman, D.W., 1988. Bacterivorous nematodes and organic matter decomposition. Agric. Ecosyst. Environ. 24: 195-217.

[10] Ferris, H., et al., 1996. Dynamics of nematode communities in tomatoes grown in conventional and organic farming systems, and their impact on soil fertility. Appl. Soil Ecol. 3: 161-175.

[11] Le Van Khoa et al., 2000. Analysis manual of soil, water, fertilizer and plant. Educational Publishing. 304p. $70-74$.

[12] Linford et al., 1938. Reduction of soil populations of the root-knot nematode during decomposition of organic matter. Soil Science, 45: 127-141.

[13] Linford, M. B., 1937. Stimulated activity of natural enemies of nematodes. Science, 85: 123-124.

[14] Neher D.A., 2001. Role of Nematodes in Soil Health and their use as indicators. Journal of Nematology, 33: 161-168.

[15] Nguyen Ngoc Chau, Nguyen Vu Thanh, 2000. Fauna in Vietnam (22). Science and Technics Publishing, Hanoi.

[16] Nguyen $\mathrm{Vu}$ Thanh, 2007. Fauna in Vietnam (4). Science and Technics Publishing, Hanoi.

[17] Nguyen Ngoc Chau and Vu Thanh Tam, 2005. Study on using nematode to assess the environmental quality of agroecosystem soil. Proceedings of the 1st National Scientific Conference on Ecology and Biological Resources Hanoi, p. 690-697.

[18] Porazinskaa D.L., et al., 1999. Nematode communities as indicators of status and processes of a soil ecosystem. Applied Soil Ecology, 13: 69-86.

[19] Robert Mcsorley, 2011. Overview of Organic Amendments for Management of Plant-Parasitic Nematodes, with Case Studies from Florida. Journal of Nematology, 43(2): 69-81.

[20] Smol N., 2007. General techniques. Lecture Book of International nematology course. Ghent University, p. 1-38. 
[21] Tom Bongers, 1990. The maturity index: An ecological measure of environmental disturbance based on nematode species composition. Oecologia 83: 14-19.

[22] Yeates, et al., 1993a. Feeding habits in soil nematode families and genera. An outline for soil ecol- ogists. J. Nematol., 25: 315-331.

[23] Yeates, et al., 1997. Faunal and microbial diversity in three Welsh grassland soils under conventional and organic management regimes. J. Appl. Ecol. 34: 453-470. 